\title{
Livestock Browsing, Not Water Limitations, Contributes to Recruitment Failure of Dobera glabra in Semiarid Ethiopia
}

\author{
Diress Tsegaye, ${ }^{1}$ Stein R. Moe, ${ }^{2}$ and Mitiku Haile ${ }^{3}$
}

Authors are ${ }^{1}$ Research Fellow and ${ }^{2}$ Associate Professor, Department of Ecology and Natural Resources Management, Norwegian University of Life Sciences, PO Box 5003, 1432 ÅS, Norway; and ${ }^{3}$ Professor, Department of Land Resource Management and Environmental Protection, Mekelle University, PO Box 231, Mekelle, Ethiopia.

\begin{abstract}
The study used nursery and field experiments to investigate why recruitment of Dobera glabra (Forssk) Poir., a native food source for both humans and livestock, often fails in the semiarid rangelands of Afar, Ethiopia. We hypothesized that soil water limitations and browsing by livestock would be the primary mechanisms accounting for the failure of natural regeneration. We used three sets of experiments-1) seedling performance in response to shade and watering in a nursery, 2) field regeneration with and without browsing, and 3) regeneration beneath trees with and without browsing-to examine regeneration success. Seedlings were established in plots from seeds sown directly into the soil for nursery and field experiments, but natural germination occurred beneath trees. Survival and relative growth rates (RGR) were used to monitor seedling performance. Seedlings that received neither shade nor watering treatments had lower seedling survival $(53 \pm 15 \%)$ as compared with other treatment combinations. Highest seedling survival was recorded under shade and $1 \mathrm{~d}$ watering $\cdot \mathrm{wk}^{-1}$ treatment combinations $(92 \pm 1 \%)$. However, shade treatments had a minimal increase on seedling RGR. Water limitation is not a crucial limiting factor for D. glabra recruitment, as $53 \%$ of the seedlings survived without both shade and supplemental water for 1 yr. Field experiments, however, demonstrated that browsing greatly reduced seedling survival (below 15\%) and suppressed growth of surviving seedlings, suggesting that browsing is the major factor preventing natural recruitment. Natural recruitment of $D$. glabra is unlikely with the existing continuous and intensive grazing/browsing in Afar rangelands, where the mobility of pastoralists is restricted. We suggest that planting nursery-raised seedlings in home gardens of settled pastoralists and establishment of grazing reserves in some key range sites that contain D. glabra could help offset the recruitment failure of native food species D. glabra in Afar rangelands.
\end{abstract}

\section{Resumen}

Este estudio utilizó datos de viveros así como experimentos de campo para investigar por qué el establecimiento natural de Dobera glabra (Forssk) Poir., que es una fuente de alimentación tanto para los seres humanos como para el ganado, a menudo falla en las zonas semiáridas de Afar, Etiopía. Nuestra hipótesis fue que las limitaciones de agua del suelo, y el ramoneo del ganado son las causas principales del fracaso del establecimiento natural. Utilizamos tres grupos de experimentos: 1) el rendimiento de plántulas en respuesta a la sombra y riego en un vivero, 2) el establecimiento en forma natural (campo) con y sin ramoneo, y 3) establecimiento debajo de los árboles con y sin ramoneo para examinar el éxito del mismo. Las plantas en los viveros se establecieron en parcelas de semillas sembradas directamente en el suelo tanto en los viveros como en los experimentos de campo, pero la germinación natural se llevó a cabo debajo de árboles. Se utilizo la sobrevivencia y tasas de crecimiento relativo (RGR) para evaluar el rendimiento de las plántulas. Las plántulas en los tratamientos donde no recibió ni agua ni sombra presentaron los niveles más bajos de sobrevivencia $(53 \pm 15 \%)$, en comparación con la combinación de los otros tratamientos. Los niveles más altos de sobrevivencia se registraron en la combinación de tratamientos de sombra con un día de riego por semana $(92 \pm 1 \%)$. Sin embargo, las plántulas de los tratamientos de sombra tuvieron un incremento mínimo en RGR. La carencia del agua no es un factor limitante para el establecimiento D. glabra el establecimiento de un $53 \%$ de sobrevivencia se observó en plántulas sin sombra y agua adicional por un año. Sin embargo, los experimentos del campo, demostraron que el ramoneo seriamente reduce la sobrevivencia de las plántulas (por abajo $15 \%$ ) y reduce el crecimiento de las plántulas que sobreviven, sugiriendo que el ramoneo es el factor principal que previene el establecimiento natural. El establecimiento natural de D. glabra es poco probable con la forma contínua e intensiva de pastoreo/ramoneo en los pastizales de Afar, donde la movilidad de los pastores es restringida. Sugerimos que el plantar esta especie en viveros en las casas de los pastores establecidos y el proporcionar áreas de reserva de pastoreo en algunas áreas claves del pastizal que tengan D. glabra podría ayudar a reducir la falla del establecimiento de especies nativas como D. glabra en los pastizales de Afar.

Key Words: Afar pastoralists, herbivory, seedling survival, tree regeneration

Research was funded by the Development Fund of Norway and the Norwegian State Education Loan Fund.

Correspondence: Diress Tsegaye, Dept of Ecology and Natural Resources Management, Norwegian University of Life Sciences, PO Box 5003, 1432 ÅS, Norway. Email: diress. alemu@umb.no or diress62@yahoo.com

Manuscript received 20 October 2008; manuscript accepted 17 July 2009,

\section{INTRODUCTION}

Trees play a central role in the exploitation strategies of pastoralists who occupy the arid and semiarid areas in Africa through providing browse for livestock during the long dry season and other services, such as wild fruit and medicine to 
humans (Le Houerou 1980; Reid and Ellis 1995). However, poor seedling recruitment is often a major factor affecting the structure and composition of savanna woodlands in these areas (e.g., Laws 1970; Pellew 1984; Dublin et al. 1990; Ruess and Halter 1990). Some woody species in these areas have tended to disappear, as natural regeneration is inadequate (Menaut et al. 1995). Thus, understanding factors that determine the recruitment dynamics of woody plants in arid and semiarid areas is important where there is a shift from grassland to woodland or vice versa (Belsky 1989; Bond et al. 2001).

Seedling establishment is a critical stage for plant recruitment in the semiarid and arid regions where there are stress factors such as intense herbivory (Dublin et al. 1990; Moe et al. 2009), high temperature, and water deficit (Holmgren et al. 1997; Prider and Facelli 2004) leading to increased seedling mortality. Tree recruitment may, therefore, depend on either plant tolerance to herbivory (e.g., Coley 1983), low herbivore abundance during seedling establishment (Weltzin et al. 1998; Moe et al. 2009), suppression by dense grass cover (Hoffmann et al. 2004; Riginos and Young 2007), or climatic conditions (Ray and Brown 1995; Angassa and Oba 2008). Recent work has focused mainly on the role of grazing herbivores (Angassa and Baars 2000; Oba et al. 2000) and rainfall variability (e.g., Ray and Brown 1995; Sullivan and Rhode 2002) as major drivers of vegetation change in African rangelands, while the impact of browsing herbivores on woody species regeneration has received less attention. Grazing herbivores are associated with an increase in woody species at the expense of herbaceous species (e.g., Scholes and Archer 1997; Oba et al. 2000), while browsing herbivores may prevent grasslands from becoming woodlands through repeated browsing of mainly seedlings and saplings in African savannas (e.g., Pellew 1983, 1984; Belsky 1989; Dublin et al. 1990). Some studies have shown that medium-sized ungulates are able to control woodland regeneration in savannas (e.g., Belsky 1984; Mwalyosi 1990; Prins and van der Jeugd 1993; Sinclair 1995; Moe et al. 2009). Experimental work in Kenya showed that Acacia drepanolobium Harms ex Sjöstedt experienced $86 \%$ browse damage in the absence of grasses, suggesting that presence of grasses protects saplings from browsing herbivores (Riginos and Young 2007). Thus, tree recruitment in African rangelands appears to depend on a variety of factors interacting positively or negatively.

Besides understanding the role of browsing herbivores on recruitment of trees, the effect of water limitation on tree recruitment is important. Plant growth in arid and semiarid areas is strongly limited by water availability (Prider and Facelli 2004). Some studies indicate that seedling growth of some species is facilitated through improved moisture availability (i.e., lower evaporative demands) under plant canopies due to reduced temperatures (Belsky et al. 1989; Callaway 1997; Prider and Facelli 2004), while other studies (e.g., Midgley and Bond 2001) show that some species regenerate better without shade. Although contrasting responses to shade have been reported for different species, shade may reduce the impact of moisture stress by reducing water loss from soil and plants during the long dry season and improve the performance of seedlings in the arid and semiarid systems (Holmgren et al. 1997). Much remains unknown about the facilitative and detrimental effects of shade for many plants in arid and semiarid areas of Africa, although studies in other dry areas have revealed facilitative roles of shade under stressful conditions (Callaway 1995; Maestre et al. 2003; Prider and Facelli 2004).

The process of establishment and growth of seedlings of many woody species is still poorly known, particularly in subSaharan African rangelands, where land use changes have brought considerable disturbances to ecosystems. Except for a few attempts that have studied the effect of overgrazing and subsequent bush encroachment (Angassa and Baars 2000; Angassa 2002; Abule et al. 2007; Solomon et al. 2007), efforts to study the influence of herbivores and moisture-related factors on woody species recruitment are nonexistent for Ethiopian rangelands. One woody species of high food security importance for the pastoral Afar people in northern Ethiopia is the evergreen wild fruit tree, Dobera glabra (Forssk) Poir. Dobera glabra is a valuable woody species that provides browse for animals, edible fruits and seeds, shade, firewood, timber, and medicine for humans (Fasil et al. 2001; Tsegaye et al. 2007). As informed by the Afar pastoralists, D. glabra is unique for its provision of fruits at the end of the long dry season, when other products like milk are limited and the seeds are stored for food security during periods of drought. Recently, there appears to be a serious concern among Afar pastoralists about the lack of recruitment of D. glabra, as young seedlings, to replace the existing adults, are almost absent in the rangeland sites where the plant is occurring. The lack of regeneration seems a widespread problem in the arid and semiarid habitats where the species grows, but attempts have not been made to address the causes so far.

Here, we address why the economically important wild fruit tree (D. glabra) fails to successfully regenerate from seed in the Afar rangelands. We examined the effects of moisture and browsing on seedlings of D. glabra to determine their effect on recruitment into adult size classes. The failure of recruitment of D. glabra could possibly be caused by several factors. Seed production and/or dispersal could be limited, seed predation and seedling herbivory could be excessive, seedling establishment could be reduced by moisture stress, or there could be limited shade by herbaceous vegetation or tree canopies during periods of moisture stress. In this study, we investigate two of these hypotheses: first, that moisture limitation accounts for the failure of seedling establishment and, second, that recruitment is suppressed by high levels of herbivory on the seedlings. The moisture limitation hypothesis rests on the observation that climate change in the arid and semiarid areas, including the study area, has resulted in a decline in the rainfall amount and in high evaporation rates (Coppock 1994). The herbivory hypothesis is supported by the presence of high livestock densities in the study area (Tsegaye et al. 2003).

\section{METHODS}

\section{Study Site}

The study was conducted in northern Afar rangelands of Ethiopia (lat $13^{\circ} 15^{\prime} \mathrm{N}$, long $39^{\circ} 50^{\prime} \mathrm{E}$ ). The study area is occupied by Afar seminomadic pastoral and agropastoral people, engaged mainly in traditional lifestyles. The seminomadic pastoralists exploit the temporal and spatial heterogeneity of feed and water resources for their animals (Tsegaye et al. 1999a, 1999b). Agropastoralists maintain a fixed residence 
in a village and practice some agriculture. The establishment of permanent and semipermanent residences, caused by centralized administrations and spontaneous own individual and collective settlements, has become a common practice by Afar pastoralists and resulted in curtailment of seasonal mobility in recent years (Gamaledin 1993). The rangeland resources are utilized mainly by domestic herbivores like goats, camels, sheep, cattle, and donkeys in the order of their numbers and importance to the Afar people (Tsegaye et al. 1999a).

The study area has a long dry season and two wet seasons (long rainy season from July to September and only few showers during March/April). Annual precipitation ranges between $150 \mathrm{~mm}$ and $500 \mathrm{~mm}$ (Hunting Technical Services 1976; Tsegaye et al. 1999a). Besides the long dry season, the study area experiences recurrent drought where either the short or the long or both rains may fail (Tsegaye et al. 1999a). For instance, there was no rainfall during the short rainy season in 2007.

The study area is dominated by Acacia species with no or poor herbaceous cover during the dry season (Tsegaye et al. 1999a). The study species, D. glabra, is among the wild food plants for livestock as well as humans. The species is particularly important for food security during the dry season (Fasil et al. 2001; Tsegaye et al. 2007). Dobera glabra is not only found in the eastern and southern rangelands of Ethiopia but is also common in many other locations across the rangelands of the Horn of Africa and East Africa and in the Middle East (BekeleTesemma et al. 1993; Tsegaye et al. 2007; International Centre for Research in Agroforestry 2008). A study on the abundance of D. glabra in the study area showed a mean density of 13.6 individuals $\cdot \mathrm{ha}^{-1}$ for matured shrubs and trees combined, while seedling density was only 0.4 individuals $\cdot \mathrm{ha}^{-1}$, confirming poor regeneration (D. Tsegaye, M. Haile, and S. R. Moe, unpublished data, 2009). Thus, D. glabra was chosen for this study on the basis of its socioeconomic and ecological importance and because of local concerns about the recruitment failure.

\section{The Experiments}

We used three sets of experiments: 1) seedling performance in response to shade and water availability in a nursery, 2) field regeneration with and without browsing, and 3) regeneration beneath trees with and without browsing. The seedlings used at nursery and field experiments were germinated in established plots from seeds artificially planted directly into the soil during the 2006 main rainy season. But the seedlings beneath trees were naturally germinated during the same season. The initial seedling conditions vary in each plot as the number of germinated seeds differs. Out of the 20 seeds planted in each plot $\left(1 \mathrm{~m}^{2}\right)$, the overall mean initial number of seedlings per plot was 12 (range 5-19 seedlings) and 9 (range 5-18 seedlings) in a nursery and in the field, respectively. Thus, the variation that may be caused by the initial number and height of seedlings was taken care of during data analysis. All the plots for the naturally germinated seedlings beneath trees had equal number of seedlings (15 seedlings per plot). We used survival and growth parameters to evaluate seedling performance to the experimental treatments.

\section{Nursery Experiment}

We monitored seedling survival and growth after manipulating shade and watering treatments. The seedlings were either shaded to reduce evapotranspiration or left open and received three different watering treatments: 1) no watering, 2) $1 \mathrm{~d}$ watering $\cdot \mathrm{wk}^{-1}$, and 3) $3 \mathrm{~d}$ watering $\cdot \mathrm{wk}^{-1}$. Thus, the experiment had six treatment combinations (shade $\times$ watering) replicated 15 ( $n=15$ plots) and 20 ( $n=20$ plots) times, giving a total of 90 and 120 plots for seedling survival and growth monitoring, respectively. The experimental plots were laid out in such a way that all the plots were divided into three groups, and each group randomly received one of the three watering treatments. Then each group was again subdivided into two groups, and each subgroup randomly received one of the two shade treatments.

Seedlings receiving shading treatment were grown under shading beds (raised $25 \mathrm{~cm}$ from the ground at the beginning and increased as the seedlings grow) made from local dry grass woven into mats. The shade material was used to simulate the natural tree or shrub canopies or similar herbaceous cover. Plots receiving watering treatments were watered to field capacity (until the soils were saturated) during the study period, and the amount of water added to each plot at a time was about 5-7 L during the rainy season and increased to $12-15 \mathrm{~L}$ per plot during the dry season.

We recorded seedling survival (i.e., as number of success or failure) and height every month for $1 \mathrm{yr}$. Then we calculated relative growth rate in height (RGR) for 12 mo (from October 2006 to September 2007) following Hunt (1990) as $\mathrm{RGR}=\left(\mathrm{LnH}_{12}-\mathrm{LnH}_{0}\right) /\left(\mathrm{t}_{12}-\mathrm{t}_{0}\right)$, where $\mathrm{H}_{0}$ and $\mathrm{H}_{12}$ are the height measurements at the beginning and end of the experiment, respectively.

To quantify the shoot and root dry masses and the ratio of seedling height to root length, five seedlings from each of unshaded watering treatments were randomly sampled after the 12 -mo growth period. Seedlings were carefully uprooted, and the roots were washed using a fine-mesh wire sieve to remove soil while retaining the fine roots. Then the shoot heights and root lengths were measured. The shoot and root parts were separated and oven dried (at $105^{\circ} \mathrm{C}$ for $24 \mathrm{~h}$ ) to a constant weight to determine dry mass.

To further examine to what extent seedling survival was affected by moisture stress (i.e., drought) or other factors, we estimated the relative importance of drought as a cause of seedling mortality $(I)$ and a drought sensitivity parameter $\left(D_{s}\right)$ during the 9 mo in the dry season for the nursery experiment following Engelbrecht et al. $(2005,2007)$ :

$$
\begin{aligned}
I & =\left(\mathrm{M}_{\mathrm{D}}-\mathrm{M}_{\mathrm{W}}\right) / \mathrm{M}_{\mathrm{D}} \\
D S & =\left(\mathrm{S}_{\mathrm{W}}-\mathrm{S}_{\mathrm{D}}\right) / \mathrm{S}_{\mathrm{W}} \times 100
\end{aligned}
$$

where $\mathrm{M}_{\mathrm{W}}=$ mortality in the watered plots, $\mathrm{M}_{\mathrm{D}}=$ mortality in the dry plots (nonwatered), I includes direct drought effects and may sometimes include mortality due to interactions between drought and other factors (ranges from 0 to 1 ), and $S_{\mathrm{W}}$ and $S_{\mathrm{D}}$ are the seedling survival over 9 mo during the dry season for watered and nonwatered plots, respectively.

\section{Field Experiment}

We manipulated two main treatments for the field experiment: "protected" and "open" plots established in two sites having different disturbance regimes ("disturbed" and "highly dis- 
Table 1. Seedling survival of Dobera glabra in response to shade (vs. no shade), watering treatments (no watering, $1 \mathrm{~d}$ watering $\cdot$ wk ${ }^{-1}$, and $3 \mathrm{~d}$ watering $\cdot \mathrm{wk}^{-1}$ ) in a nursery and plot type (herbivore exclusion vs. open plots) at different range sites (disturbed vs. highly disturbed) beneath trees (open vs. protected) analyzed using the generalized linear model (family = binomial, link = logit). One level of each categorical variable is used as a reference and serves as a contrast $(\beta=0)$ to the other levels. The levels in parentheses are used as a reference for each categorical variable.

\begin{tabular}{|c|c|c|c|c|}
\hline Effect & $\beta$ & SE & $z$ & $P$ \\
\hline \multicolumn{5}{|l|}{ 1. Nursery experiment $(N=90$, Res. $d f=84)$} \\
\hline Constant & 0.11 & 0.19 & 0.57 & \\
\hline Shade (vs. no shade) & 1.7 & 0.28 & 6.00 & $<0.0001$ \\
\hline $1 \mathrm{~d}$ watering $\cdot$ wk $^{-1}$ (vs. no watering) & 0.89 & 0.27 & 3.35 & 0.001 \\
\hline $3 \mathrm{~d}$ watering $\cdot \mathrm{wk}^{-1}$ (vs. no watering) & 1.04 & 0.25 & 4.20 & $<0.0001$ \\
\hline Shade $\times 1 \mathrm{~d}$ watering $\cdot \mathrm{wk}^{-1}$ (vs. no shade $\times$ no watering) & -0.30 & 0.42 & -0.72 & 0.47 \\
\hline Shade $\times 3 \mathrm{~d}$ watering $\cdot \mathrm{wk}^{-1}$ (vs. no shade $\times$ no watering) & -0.84 & 0.39 & -2.15 & 0.03 \\
\hline \multicolumn{5}{|l|}{ 2. Field experiment $(N=60$, Res. $d f=56)$} \\
\hline Constant & -2.14 & 0.32 & -6.70 & \\
\hline Highly disturbed site (vs. disturbed) & 0.37 & 0.45 & 0.83 & 0.41 \\
\hline Protected plot (vs. open) & 2.73 & 0.35 & 7.71 & $<0.0001$ \\
\hline Highly disturbed site $\times$ protected (vs. disturbed $\times$ open) & -1.01 & 0.49 & -2.04 & 0.04 \\
\hline \multicolumn{5}{|l|}{ 3. Beneath trees $(N=16$, Res. $d f=14)$} \\
\hline Constant & -2.11 & 0.29 & -7.18 & \\
\hline Protected plot (vs. open) & 2.44 & 0.35 & 7.04 & $<0.0001$ \\
\hline
\end{tabular}

turbed"). The disturbed site is a communal grazing land with few nearby small villages, and the highly disturbed site is used as communal grazing land with adjacent cultivated areas and many permanent villages. For each site, 30 plots were established with $50 \mathrm{~m}$ of spacing between them in a 5-ha area of relatively uniform range site. In each site, half the 30 plots were randomly selected and protected from natural herbivory (i.e., exclude domestic and large wild herbivores), and the other half were left open to natural herbivory. Thus, the field experiment had four treatment combinations (site $\times$ plot type) replicated 15 times ( $n=15$ plots), giving a total of 60 plots for seedling survival and growth monitoring. We manipulated herbivory pressure by protecting seedlings from browsing animals, except small rodents and insects. Herbivore exclusion was achieved by constructing a cage made of local materials with a mesh size of $2 \mathrm{~cm}$, and clan leaders were used to convince herders not to remove or damage cages.

Similar to the nursery experiment, we recorded seedling survival every month and RGR for 12 mo (from October 2006 to September 2007). In addition, seedling survival and RGR of naturally germinated seedlings beneath trees were monitored by establishing a total of 16 plots beneath trees. Eight plots were fenced to exclude domestic and large wild herbivores, and the remaining half were left open. As data were not recorded for seedlings beneath trees for some months because of security reasons, only four months (October, January, June, and September) of records were used for data analysis.

\section{Data Analysis}

To assess the effects of shade and watering treatments at nursery, plot type, and site conditions in the field and plot type beneath trees, we used seedling survival and RGR as response variables. We also included initial seedling condition (i.e., initial number) as a covariate while analyzing seedling survival for both nursery and field experiments. Both seedling survival and RGR data were analyzed by the generalized linear models in $\mathrm{R}$ software version 2.7.0 (R Development Core Team 2008). We used a binomial error distribution (with logit link) to analyze seedling survival as data were recorded as a binary response variable (i.e., number of success or failure; Crawley 2007). For RGR we used normal error distribution. To avoid pseudoreplication, we treated each $1-\mathrm{m}^{2}$ plot as a replicate by averaging individual seedling height. After 12 mo, seedling mortality resulted in zero counts in some replicates, particularly in open plots in the field experiment. Therefore, only plots that had live seedlings were included in the analysis for RGR.

In those cases in which a variable was found to be insignificant, it was removed from the model following Crawley (2007). For all analyses, results in which $P<0.05$ are reported as significant. However, marginal significance was considered and reported whenever $P<0.1$ and pairwise comparisons show significant differences for some levels of treatments.

\section{RESULTS}

\section{Nursery Experiment}

As compared with control survival at nursery was high for seedlings that received either supplementary watering ( $1 \mathrm{~d}$ or 3 $\mathrm{d} \cdot \mathrm{wk}^{-1}$ ) or shade or a combination of shade and watering (Table 1). After $1 \mathrm{yr}$, seedlings that neither were shaded nor watered had low survival $(53 \pm 15 \%$, mean $\pm \mathrm{SD}, P<0.0001)$ compared with the other treatments (Fig. 1A; Table 1). Nonshaded seedlings that received water either $1 \mathrm{~d} \cdot \mathrm{wk}^{-1}$ $(73 \pm 18 \%, P=0.04)$ or $3 \mathrm{~d} \cdot \mathrm{wk}^{-1} \quad(76 \pm 15 \%, P=0.03$; Fig. 1A) had low seedling survival as compared with shaded and $1 \mathrm{~d} \cdot \mathrm{wk}^{-1}(92 \pm 1 \%)$ watered plants (Fig. 1B; Table 1). Overall, the result at nursery suggested that D. glabra seedlings require either shading or supplementary watering for better survival, although $53 \%$ survival was achieved in the 

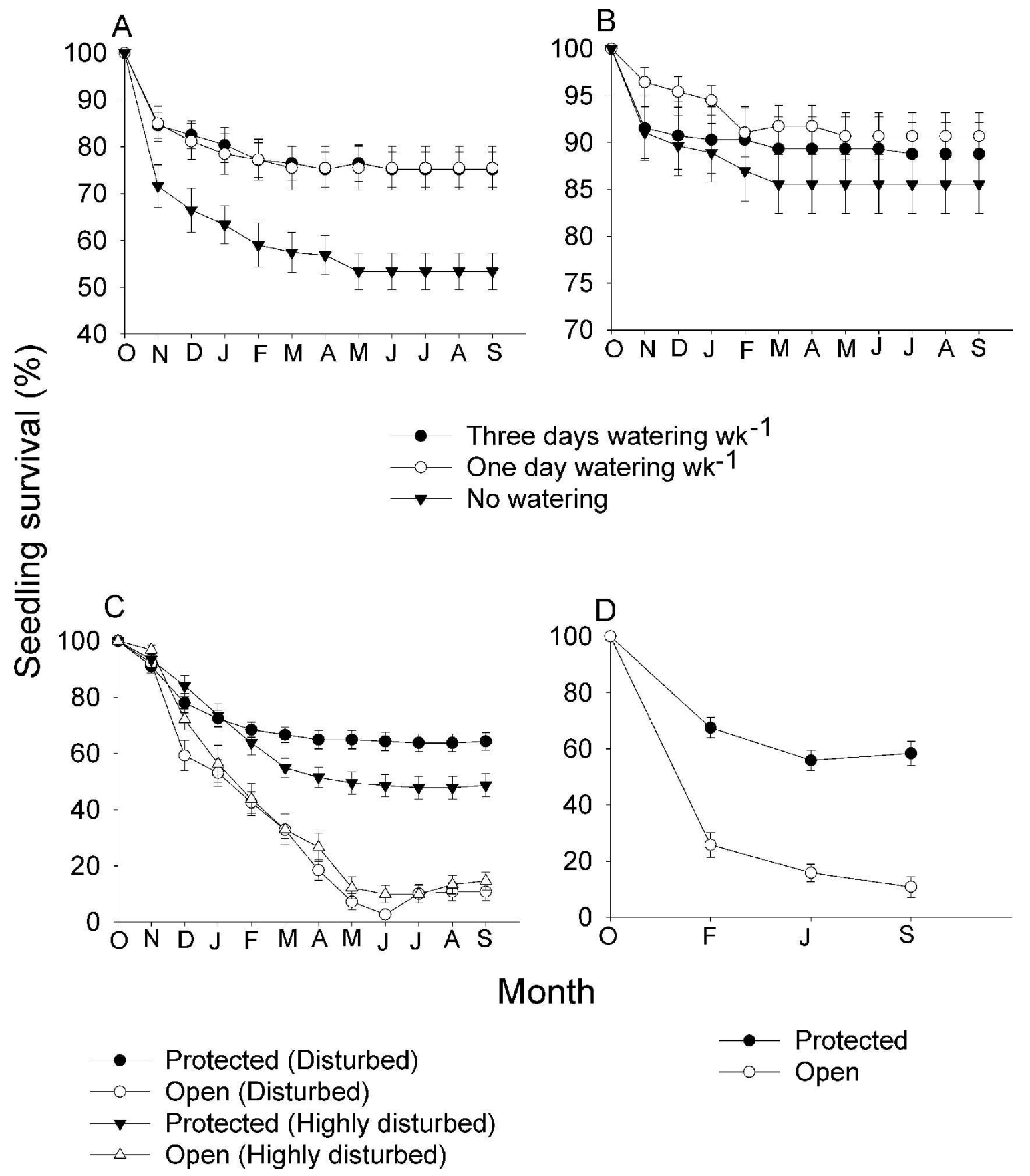

$\longrightarrow$ Protected

$\multimap$ Open

Figure 1. Percentage survival $( \pm \mathrm{SE})$ of Dobera glabra seedlings in response to watering treatments without shade $(\mathbf{A})$ and with shade $(\mathbf{B})$ in a nursery, browsing exclusion experiment in the field (C), and beneath trees (D).

absence of both shade and watering treatments. The variation in the initial number of seedlings per plot did not affect seedling survival in the nursery experiment and is therefore not shown in Table 1.

The mean relative importance of drought $(I)$ and other nondrought factors as a cause of seedling mortality was $47 \%$ in the nonwatered plots (Fig. 2). D. glabra seedling sensitivity to drought was only $28 \%$, suggesting that moisture limitation is not a serious constraint for seedling survival (Fig. 2). Similar to the watered treatments, the remaining additional mortality in the nonwatered treatment was caused by other nondrought factors.
At the nursery, growth rate (RGR) of D. glabra seedlings was significantly affected by levels of watering and marginally affected by the interacting effects of shade and watering treatments (Table 2). Seedling growth rates were similar for all treatment combinations except for control treatment combination. Seedlings that received neither shade nor watering treatments had lower RGR $(0.13 \pm 0.04)$ as compared with no shade $\times 3 \mathrm{~d} \cdot \mathrm{wk}^{-1}(0.18 \pm 0.05, P=0.005)$ or shade $\times 1$ $\mathrm{d} \cdot \mathrm{wk}^{-1}(0.19 \pm 0.04, P=0.008)$ or shade $\times 3 \mathrm{~d} \cdot \mathrm{wk}^{-1}(0.18 \pm$ $0.04, P=0.03$ ) watered plants (Fig. 3A).

A higher ratio of root length to shoot height was recorded for all watering treatment combinations (Table 3). However, the 


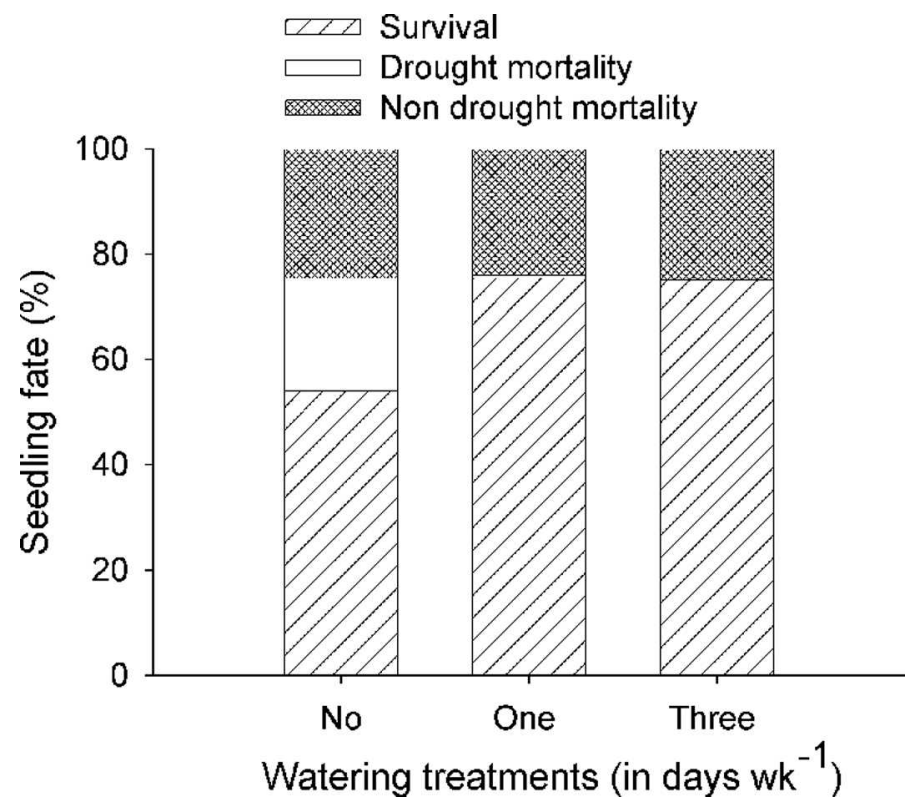

Figure 2. Relative importance of water limitations as the cause of Dobera glabra seedling mortality for watered and nonwatered treatments in a nursery during the dry season.

nonwatered seedlings had a relatively higher ratio of root length to shoot height as compared with the watered plots. As shown in Table 3, the ratio of root to shoot dry mass was highest for nonwatered plots as compared with the watered plots.

\section{Field Experiment}

After $1 \mathrm{yr}$, protected plots had higher seedling survival as compared with open plots in both disturbed and highly disturbed sites, suggesting that browsing increased the seedling mortality substantially (Fig. 1C; Table 1). When protected from browsing, disturbed site $(64 \pm 12 \%)$ had higher seedling survival compared to highly disturbed sites $(49 \pm 16 \%)$ (Fig. 1C; $P=0.004$ ). For open plots, seedling survival dropped rapidly in both sites (Fig. 1C), resulting in $85-90 \%$ seedling mortality within a period of 9 mo (Fig. 1C). A slight increase in survivorship of $1-2 \%$ was observed within the long rainy season in 2007 (July-September) because some seedlings previously recorded as dead were able to regenerate (Fig. 1C).

Similarly, monitoring of naturally germinated seedlings beneath D. glabra trees for a 1-yr period showed large differences between protected $(58 \pm 11 \%)$ and open (11 $12 \%$ ) plots for seedling survival (Fig. 1D; Table 1; $P<$ $0.0001)$. In general, seedlings from protected plots in the field and beneath trees had relatively similar survival as seedlings from the control treatments in the nursery experiment (Figs. 1A, $1 \mathrm{C}$, and $1 \mathrm{D})$.

Growth rate (RGR) of seedlings differed between open and protected plots in both the disturbed and the highly disturbed sites (Table 2). Growth rate of seedlings were negative for open plots in both sites (Fig. 3B), indicating that repeated browsing reduced seedling height to a level below the initial height. Seedling growth was substantially improved when seedlings were protected from browsing (Fig. 3B; Table 2). Similarly, growth rate of seedlings was poor for open plots $(0.01 \pm 0.01)$ as compared with protected plots $(0.12 \pm 0.02)$ when monitored beneath trees for $1 \mathrm{yr}(P<0.001$; Fig. 3C; Table 2$)$.

\section{DISCUSSION}

Consistent with our hypotheses, D. glabra recruitment was facilitated by shade and watering treatments and negatively affected by browsing in Afar rangelands. D. glabra seedlings that received either supplementary watering $\left(1\right.$ or $\left.3 \mathrm{~d} \cdot \mathrm{wk}^{-1}\right)$ or shade or a combination of shade and watering had higher

Table 2. Relative growth rates of Dobera glabra seedlings in response to shade (vs. no shade), watering treatments (no watering, 1 d watering $\cdot w^{-1}$, and $3 \mathrm{~d}$ watering $\cdot \mathrm{wk}^{-1}$ ) in a nursery and plot type (herbivore exclusion vs. open plots) at different range sites (disturbed vs. highly disturbed) beneath trees (open vs. protected) analyzed by the generalized linear model using a normal error. One level of each categorical variable is used as a reference and serves as a contrast $(\beta=0)$ to the other levels. The levels in parentheses are used as a reference for each categorical variable.

\begin{tabular}{|c|c|c|c|c|}
\hline Effect & $\beta$ & SE & $t$ & $P$ \\
\hline \multicolumn{5}{|l|}{ 1. Nursery experiment $(N=110$, Res. $d f=104)$} \\
\hline Constant & 0.13 & 0.01 & 9.78 & \\
\hline Shade (vs. no shade) & 0.04 & 0.02 & 2.54 & 0.01 \\
\hline $1 \mathrm{~d}$ watering $\cdot$ wk $^{-1}$ (vs. no watering) & 0.04 & 0.02 & 2.32 & 0.02 \\
\hline $3 \mathrm{~d}$ watering $\cdot \mathrm{wk}^{-1}$ (vs. no watering) & 0.06 & 0.02 & 3.72 & 0.0003 \\
\hline Shade $\times 1 \mathrm{~d}$ watering $\cdot \mathrm{wk}^{-1}$ (vs. no shade $\times$ no watering) & -0.02 & 0.02 & -1.02 & 0.31 \\
\hline Shade $\times 3 \mathrm{~d}$ watering $\cdot \mathrm{wk}^{-1}$ (vs. no shade $\times$ no watering) & -0.05 & 0.02 & -2.34 & 0.02 \\
\hline \multicolumn{5}{|l|}{ 2. Field experiment $(N=49$, Res. $d f=45)$} \\
\hline Constant & -0.01 & 0.02 & -0.37 & \\
\hline Highly disturbed site (vs. disturbed) & -0.09 & 0.02 & -4.68 & $<0.0001$ \\
\hline Protected plot (vs. open) & 0.18 & 0.02 & 9.64 & $<0.0001$ \\
\hline Highly disturbed site $\times$ protected (vs. disturbed $\times$ open) & 0.07 & 0.02 & 2.87 & 0.01 \\
\hline \multicolumn{5}{|l|}{ 3. Beneath trees $(N=13$, Res. $d f=11)$} \\
\hline Constant & 0.01 & 0.01 & 1.62 & \\
\hline Protected plot (vs. open) & 0.11 & 0.01 & 12.17 & $<0.0001$ \\
\hline
\end{tabular}



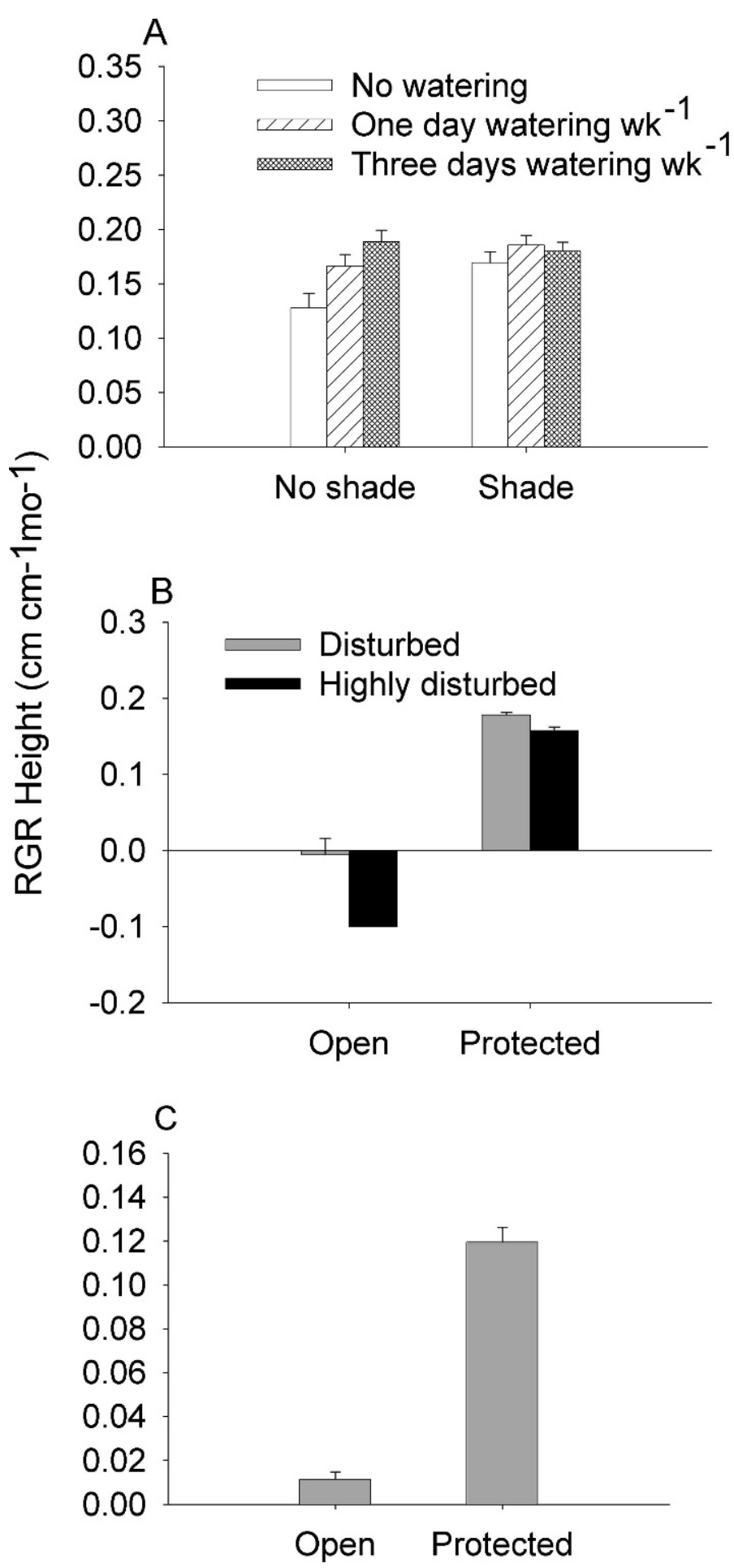

Figure 3. Relative growth rate $(\mathrm{RGR} \pm \mathrm{SE})$ of Dobera glabra seedling in response to shade and watering treatments in a nursery $(\mathbf{A})$, browsing exclusion experiment in the field (B), and beneath trees (C).

survival compared with control plants in the 1-yr nursery experiment. D. glabra seedlings had higher survival rates with increasing supplementary watering when grown without shade compared to when it was shaded. This suggests that water deficit is partially compensated for by shade during the long dry season. Our findings revealed that supplemental water improves seedling survival by $20 \%\left(1 \mathrm{~d}\right.$ watering $\left.\cdot \mathrm{wk}^{-1}\right)$ and
$22 \%$ ( $3 \mathrm{~d}$ watering $\cdot \mathrm{wk}^{-1}$ ) when grown without shade, but the increase was $34 \%$ when shaded without water addition.

Shade becomes an advantage with drier conditions. Thus, seeds germinating under shrub or herbaceous cover may have a better chance of establishment than those germinating in the open. Prider and Facelli (2004) reported that shade dependence may be due to different combinations of physiological traits, but further experimental studies are needed to test such relationships for D. glabra. Liancourt et al. (2005) also reported that facilitation of woody seedling survival is driven by the retention of water by vegetation cover. For instance, a study in southern Australia indicated that Enchylaena and Rhagodia species were able to persist in their habitat because of the positive benefits of Acacia canopies (Prider and Facelli 2004). Another study in Mediterranean semiarid climate indicated that the presence of a perennial grass cover facilitated the survival of shrub (Pistacia lentiscus) seedlings (Maestre et al. 2003).

Overall seedling survival of $53 \%$ in the absence of both shade and supplemental water suggests that D. glabra seedlings may persist if there are no additional limiting factors. Confirming this scenario, D. glabra seedling sensitivity to drought for nonwatered plots in the nursery was only $28 \%$, implying that D. glabra is drought resistant. Thus, seedling mortality for control plots in the nursery was caused by a combination of moisture stress and other non-moisture-related factors like insect pests. Our results also indicate that seedlings watered once per week perform equally with those watered three times per week, suggesting that D. glabra does not require much water for establishment. Previous studies have also shown that relative mortality due to drought is lower for species associated with dry habitats than species associated with more humid habitats (Engelbrecht and Kursar 2003; Engelbrecht et al. 2005; Zida et al. 2008). Although moisture limitation to some extent reduced the survival of nursery seedlings, some seedlings regenerated during the rainy season despite the fact that they had been without leaves during the long dry season. Seedlings that were not watered or shaded had a higher ratio of seedling root length to shoot height after $1 \mathrm{yr}$, indicating that D. glabra may allocate more resources to roots in response to moisture stress. Deep roots permit savanna species access to moist soil layers during dry periods (Hoffmann et al. 2004). Khurana and Singh (2004) also reported that some other tropical dry forest tree species seedlings had an increase in the ratio of root to shoot in response to low moisture level. In addition to resisting moisture stress (Hoffmann et al. 2004), a shift in biomass from above- to belowground may ensure better access to nutrients (Lambers and Poorter 1992).

The field experiment demonstrated that large herbivores significantly reduced both survival and growth of seedlings. Browsing by domestic animals (mainly goats and camels) was severe, resulting in the removal of more than $85 \%$ of the seedlings (i.e., number), and growth was considerably reduced for seedlings that survived. Goats and camels are kept in large numbers by Afar pastoralists because of their year-round milk production, cash income (mainly goats), and drought resistance, being able to subsist on the available browse species (e.g., D. glabra) during the long dry season (Tsegaye et al. 1999a). Other studies have also shown that large African 
Table 3. Ratio of height and dry biomass root to shoot of 1-yr seedlings in response to different supplementary watering treatments.

\begin{tabular}{|c|c|c|c|c|}
\hline \multirow[b]{2}{*}{ Parameter } & \multirow[b]{2}{*}{ Watering treatment } & \multicolumn{2}{|c|}{ Mean $( \pm S D)$} & \multirow{2}{*}{$\frac{\text { Ratio }( \pm S D)}{\text { Root:shoot }}$} \\
\hline & & Root & Shoot & \\
\hline \multirow[t]{3}{*}{ Height (cm) } & No watering & $100.4(19.14)$ & $14.2(7.60)$ & $9.2(6.16)$ \\
\hline & $1 d \cdot w^{-1}$ & $147.2(17.01)$ & $22.6(7.96)$ & $7.4(3.33)$ \\
\hline & $3 d \cdot w^{-1}$ & $116.2(53.90)$ & $15.6(6.31)$ & $7.8(3.80)$ \\
\hline \multirow[t]{3}{*}{ Biomass (g) } & No watering & $1.8(1.49)$ & $2.3(1.72)$ & $2.2(3.75)$ \\
\hline & $1 d \cdot w^{-1}$ & $3.1(1.76)$ & $5.2(3.24)$ & $0.6(0.09)$ \\
\hline & $3 d \cdot w^{-1}$ & $1.5(1.34)$ & $2.8(2.83)$ & $0.7(0.50)$ \\
\hline
\end{tabular}

herbivores have the ability to control woody vegetation through seedling predation (Sharam et al. 2006; Moe et al. 2009). In a study from Tanzania, Prins and van der Jeugd (1993) showed that Acacia trees have only been able to establish when the population of the dominant seedling browser impala (Aepyceros melampus Lichtenstein) has been low because of anthrax outbreaks. Similarly, poor seedling survival $(<15 \%)$ in plots exposed to herbivores in our field experiment supports previous findings from savanna systems dominated by wild herbivores and may explain the present even-aged and very suppressed condition of mature D. glabra shrubs in the Afar rangelands.

Previous studies have found that seedling regeneration is poor in highly disturbed environments because of high seedling predation, trampling, and poor soil nutrient conditions, among other factors (Nepstad et al. 1996; Benitez-Malvido et al. 2005). We found no seedling mortality differences between the disturbed and highly disturbed sites when left without browsing. This indicates that the level of herbivory is too high for D. glabra recruitment even in the areas with relatively low levels of other disturbances like settlement and cultivation. When D. glabra was protected from browsing seedlings, survival differed between sites, indicating that other factors, including water availability, litter, or herbaceous cover and level of insect infestations, may be of secondary importance to regeneration in different habitats. Many studies have shown that seedling response to moisture stress varies with the presence of herbaceous cover or litter (Vitousek 1984; BenitezMalvido and Kossmann-Ferraz 1999). Thus, a low amount of herbaceous cover can be one factor explaining the relatively low seedling survival in highly disturbed sites compared to disturbed sites. This relationship is also supported by our nursery experiment where seedling height increased in response to either shade or supplementary watering, indicating that high evapotranspiration in range sites with poor litter or herbaceous cover may reduce recruitment and growth to a certain extent. On the other hand, a well-developed herbaceous cover may make $D$. glabra seedlings less apparent to herbivores at early stages. Riginos and Young (2007) similarly reported that savanna tree saplings exhibited more browse damage in the absences of grasses but also argue that growth may depend on a variety of factors acting similarly or antagonistically rather than to only grass cover or herbivores alone. Vetaas (1992) also argued that such facilitative and competitive interactions together explain the coexistence between the herbaceous and woody components in savannas. Other studies, however, have indicated that tree seedlings may suffer competition with tall and dense grasses for water, nutrients, and light (Kellman 1984; Hoffmann et al.
2004; Sharam et al. 2006). This shows that results may vary for different species and regions, depending on the level of disturbance and resistance of species to browsing.

Our results indicate that seedlings in protected plots had a higher RGR, while browsing had a significantly negative effect on RGR of D. glabra seedlings. However, the overall increase in height was small even in protected plots in the field and shaded and watered plots in the nursery. On the basis of this fact, we concluded that D. glabra is a slow-growing species, as the mean height did not reach $50 \mathrm{~cm}$ in a year, even under supplementary watering, and remained below $20 \mathrm{~cm}$ in the field experiment. The slow growth of D. glabra may be associated with plant traits that confer drought resistance as reported by Leishman and Westoby (1994) for semiarid species. Seedling height in both the nursery and the field experiment increased only during a few months between June and September, which coincides with the long rainy season. Growth of seedlings was low beneath trees and could be attributed to increased shade or other physiological conditions associated with the presence of a mature tree. The slow-growing nature of D. glabra exposes it to repeated animal browsing, disrupting the apical dominance and thereby seriously retarding the overall growth (e.g., Crawley 1983). Conclusive evidence as to whether the presence of canopy species suppresses or favors seedling establishment of D. glabra will require field manipulations with and without "nurse plants" and root trenching experiments.

\section{MANAGEMENT IMPLICATIONS}

On the basis of our findings, we concluded that moisture is not a crucial limiting factor for D. glabra recruitment, as $53 \%$ of the seedlings survived in the absence of both shade and supplemental watering treatments. Similar seedling survival was achieved when herbivores were excluded from field plots. Thus, suppression by browsing represents the major threat to the successful recruitment of D. glabra in Afar rangelands.

Natural recruitment of D. glabra is unlikely under current conditions of continuous and intensive grazing/browsing in Afar rangelands, where the mobility of pastoralists is restricted. Available grazing areas for livestock have been reduced because of land use changes, such as cultivation and settlement. In addition, a reduction in the amount of annual rainfall is predicted in response to climatic change (e.g., Tews and Jeltsch 2004). These conditions may collectively reduce the availability of feed resources for livestock and accordingly result in intensified browsing of the evergreen woody species, such as D. glabra. Thus, important food species like D. glabra may 
completely disappear if management interventions are not made. The most realistic approaches will be to plant nurseryraised seedlings in safe sites where herbivory is low or in home gardens of settled pastoralists and establish grazing reserves in rangelands where D. glabra currently exists to facilitate longterm natural regeneration.

\section{ACKNOWLEDGMENTS}

We appreciate the Afar community for permitting us access to their lands and for all the information and their excellent assistance in the field. The authors wish to thank the two anonymous reviewers for their constructive and professional comments.

\section{LITERATURE CITED}

Abule, E., H. A. Snyman, and G. N. Smit. 2007. Rangeland evaluation in the middle Awash valley of Ethiopia: I. Herbaceous vegetation cover. Journal of Arid Environments 70:253-271.

Angassa, A. 2002. The effect of clearing bushes and shrubs on range condition in Borana, Ethiopia. Tropical Grasslands 36:69-76.

Angassa, A., And R. M. T. BaARS. 2000. Ecological condition of encroached and nonencroached rangelands in Borana, Ethiopia. African Journal of Ecology 38:321-328.

Angassa, A., AND G. OBA. 2008. Effects of management and time on mechanisms of bush encroachment in southern Ethiopia. African Journal of Ecology 46:186-196.

Bekele-Tesemma, A., A. Birnie, and B. Tengnas. 1993. Useful trees and shrubs for Ethiopia. Nairobi, Kenya: Swedish International Development Authority. Regional Soil Conservation Unit: Technical Handbook (No. 5). 484 p.

BelsKY, A. J. 1984. Role of small browsing mammals in preventing woodland regeneration in the Serengeti-National-Park, Tanzania. African Journal of Ecology 22:271-279.

Belsky, A. J. 1989. Landscape patterns in a semi-arid ecosystem in East-Africa. Journal of Arid Environments 17:265-270.

Belsky, A. J., R. G. Amundson, J. M. Duxbury, S. J. Riha, A. R. Ali, and S. M. Mwonga. 1989. The effects of trees on their physical, chemical, and biological environments in a semi-arid savanna in Kenya. Journal of Applied Ecology 26:1005-1024.

Benitez-Malvido, J., and I. D. Kossmann-FerRaz. 1999. Litter cover variability affects seedling performance and herbivory. Biotropica 31:598-606.

Benitez-Malvido, J., M. M. Martinez-Ramos, J. L. C. Camargo, and I. D. K. Ferraz. 2005. Responses of seedling transplants to environmental variations in contrasting habitats of Central Amazonia. Journal of Tropical Ecology 21:397-406.

Bond, W. J., K. A. Smythe, and D. A. Balfour. 2001. Acacia species turnover in space and time in an African savanna. Journal of Biogeography 28:117-128.

Callaway, R. M. 1995. Positive interactions among plants. The Botanical Review 61:306-349.

Callaway, R. M. 1997. Positive interactions in plant communities and the individualistic-continuum concept. Oecologia 112:143-149.

Coley, P. D. 1983. Herbivory and defensive characteristics of tree species in a lowland tropical forest. Ecological Monographs 53:209-233.

Coppock, D. L. 1994. The Borana Plateau of southern Ethiopia: synthesis of pastoral research, development and change, 1989-91. Addis Ababa, Ethiopia: International Livestock Research Centre for Africa. 393 p.

Crawley, M. J. 1983. Herbivory: the dynamics of animal-plant interactions. Oxford, United Kingdom: Blackwell Scientific Publications. 437 p.

Crawley, M. J. 2007. The R book. London, United Kingdom: John Wiley \& Sons. $942 \mathrm{p}$.

Dublin, H. T., A. R. E. Sinclair, and J. McGlade. 1990. Elephants and fire as causes of multiple stable states in the Serengeti-Mara woodlands. Journal of Animal Ecology 59:1147-1164.
Engelbrecht, B. M. J., L. S. Comita, R. Condit, T. A. Kursar, M. T. Tyree, B. L. Turner, And S. P. Hubbell. 2007. Drought sensitivity shapes species distribution patterns in tropical forests. Nature 447:90-82.

Engelbrecht, B. M. J., and T. A. KurSar. 2003. Comparative drought-resistance of seedlings of 28 species of co-occurring tropical woody plants. Oecologia 136:383-393.

Engelbrecht, B. M. J., T. A. Kursar, and M. T. Tyree. 2005. Drought effects on seedling survival in a tropical moist forest. Trees-Structure and Function 19:312-321.

Fasil, K., D. Tsegaye, and G. Synvanng. 2001. Traditional coping strategies of the Afar and Borana pastoralists in response to drought. Ås, Norway: Centre for International Environment and Development Studies, Dryland Coordination Group Report No. 17. 74 p.

Gamaledin, M. 1993. The decline of Afar pastoralism. In: J. Markakis [ed.]. Conflict and the decline of pastoralism in the Horn of Africa. Basingstoke, United Kingdom: Institute of Social Science Studies. p. 45-62.

Hoffmann, W. A., B. Orthen, and A. C. Franco. 2004. Constraints to seedling success of savanna and forest trees across the savanna-forest boundary. Oecologia 140:252-260.

Holmgren, M., M. Scheffer, and M. A. Huston. 1997. The interplay of facilitation and competition in plant communities. Ecology 78:1966-1975.

Hunt, R. 1990. Basic growth rate analysis. London, United Kingdom: Unwin Hyman. $112 \mathrm{p}$.

Hunting Technical Services. 1976. Tigrai rural development study, phase II main report. London, United Kingdom: Hunting Technical Services.

International Centre for Research in Agroforestry. 2008. A tree species reference and selection guide. ICRAF, Agroforestry tree database. Available at: http:// www.agroforestry.net/aflibr.html. Accessed 15 May 2008.

KeLLmAn, M. 1984. Synergetic relationships between fire and low soil fertility in Neotropical savannas: a hypothesis. Biotropica 16:158-160.

Khurana, E., and J. S. Singh. 2004. Germination and seedling growth of five tree species from tropical dry forest in relation to water stress: impact of seed size. Journal of Tropical Ecology 20:385-396.

Lambers, H., AND H. PoORTer. 1992. Inherent variation in growth rate between higher plants: a search for ecological causes and consequences. Advances in Ecological Research 23:187-261.

Laws, R. W. 1970. Elephants as agents of habitat and landscape change in East Africa. Oikos 21:1-15.

Le Houerou, H. N. 1980. The role of browse in the management of natural grazing lands. In: H. N. Le Houerou [ed.]. Browse in Africa. Addis Ababa, Ethiopia: International Livestock Centre for Africa. p. 329-338.

Leishman, M. R., and M. Westoby. 1994. The role of seed size in seedling establishment in dry soil-conditions-experimental-evidence from semiarid species. Journal of Ecology 82:249-258.

Liancourt, P., R. M. Callaway, and R. Michalet. 2005. Stress tolerance and competitive-response ability determine the outcome of biotic interactions. Ecology 86:1611-1618.

Maestre, F. T., S. Bautista, and J. Cortina. 2003. Positive interactions in plant communities and the individualistic-continuum concept. Ecology 84:31863197.

Menaut, J. C., M. Lepage, and L. Abbaide. 1995. Savannas, woodlands and dry forests in Africa. In: S. H. Bullock, H. A. Mooney, and E. Medina [EDS.]. Seasonally dry tropical forests. Cambridge, United Kingdom: Cambridge University Press. $p$. $64-92$.

Midgley, J. J., And W. J. Bond. 2001. A synthesis of the demography of African acacias. Journal of Tropical Ecology 17:871-886.

Moe, S. R., L. P. Rutina, H. Hytteborn, and J. T. du Tolt. 2009. What controls woodland regeneration after elephants have killed the big trees? Journal of Applied Ecology 46:223-230.

Mwalyosı, R. B. B. 1990. The dynamic ecology of Acacia tortilis woodland in Lake Manyara National-Park, Tanzania. African Journal of Ecology 28:189199.

Nepstad, D. C., C. Uhl, C. A. Pereira, and J. M. C. Dasilva. 1996. A comparative study of tree establishment in abandoned pasture and mature forest of eastern Amazonia. Oikos 76:25-39. 
Oba, G., Z. Mengistu, and N. C. Stenseth. 2000. Compensatory growth of the African dwarf shrub Indigofera spinosa following simulated herbivory. Ecological Applications 10:1133-1146.

Pellew, R. A. P. 1983. The impacts of elephant, giraffe and fire upon the Acacia tortilis woodlands of the Serengeti. African Journal of Ecology 21:41-74.

Pellew, R. A. 1984. The feeding ecology of a selective browser, the Giraffe (Giraffa-Camelopardalis Tippelskirchi). Journal of Zoology 202:57-81.

Prider, J. N., AND J. M. FacelLI. 2004. Interactive effects of drought and shade on three arid zone chenopod shrubs with contrasting distributions in relation to tree canopies. Functional Ecology 18:67-76.

Prins, H. H. T., and H. P. van der Jeugd. 1993. Herbivore population crashes and woodland structure in east Africa. Journal of Ecology 81:305-314.

R Development Core Team. 2008. R: a language and environment for statistical computing. Vienna, Austria: R Foundation for Statistical Computing. Available at: http://www.R-project.org. Accessed 20 January 2008.

Ray, G. J., AND B. J. Brown. 1995. Restoring Caribbean dry forests-evaluation of tree propagation techniques. Restoration Ecology 3:86-94.

REID, R. S., AND J. E. EluIs. 1995. Impacts of pastoralists on woodlands in South Turkana, Kenya-livestock-mediated tree recruitment. Ecological Applications 5:978-992.

Riginos, C., And T. P. Young. 2007. Positive and negative effects of grass, cattle, and wild herbivores on Acacia saplings in an East African savanna. Oecologia 153:985-995.

Ruess, R. W., and F. E. Halter. 1990. The impact of large herbivores on the Seronera Woodlands, Serengeti National Park, Tanzania. African Journal of Ecology 28:259-275.

SCHoles, R. J., AND S. R. ArCHeR. 1997. Tree-grass interactions in savannas. Annual Review of Ecological Systems 28:517-544.

Sharam, G., A. R. E. Sinclair, and R. Turkington. 2006. Establishment of broadleaved thickets in Serengeti, Tanzania: the influence of fire, browsers, grass competition, and elephants. Biotropica 38:599-605.

SinclaIR, A. R. E. 1995. Equilibria in plant-herbivore interactions. In: A. R. E. Sinclair and P. Arcese [EDS.]. Serengeti II: dynamics, management, and conservation of an ecosystem. Chicago, IL, USA: University of Chicago Press. p. 91-113.

Solomon, T. B., H. A. Snyman, and G. N. Smit. 2007. Cattle-rangeland management practices and perceptions of pastoralists towards rangeland degradation in the
Borana zone of southern Ethiopia. Journal of Environmental Management 82:481-494.

Sullivan, S., ANd R. Rohde. 2002. On non-equilibrium in arid and semi-arid grazing systems. Journal of Biogeography 29:1595-1618.

Tews, J., And F. JeLTSCH. 2004. Modeling the impact of climate change on woody plant population dynamics in South African savanna. BMC Ecology 4:17.

Tsegaye, D., K. O. Farah, and D. M. Mbuvi. 1999a. Impact of land use on vegetation resources with emphasis on woody vegetation in the semi-arid area of Aba'ala district, North Afar, Ethiopia [thesis]. Nairobi, Kenya: University of Nairobi. $110 \mathrm{p}$.

Tsegaye, D., K. O. Farah, and D. M. Nyariki. 1999b. Influence of settlements on land use and vegetation in the rangelands of North-eastern Ethiopia: application of aerial photographic technique. Journal of Human Ecology 10:349-356.

Tsegaye, D., M. Haile, F. Yifter, and L. Tamene. 2003. Assessment of rangeland condition and mobility pattern in north eastern Ethiopia: field survey and application of GIS. In: N. Allsopp, A. R. Palmer, S. J. Milton, K. P. Kirkman, G. I. H. Kerley, C. R. Hurt, and C. J. Brown [EDs.]. Proceedings of the VII International Rangeland Congress; 28 July-1 August 2003; Durban, South Africa. Durban, South Africa: International Rangelands Congress. $p$. 779-781.

Tsegaye, D., M. Balehgn, K. Gebrehiwot, M. Haile, G. Gebresamuel, and E. Aynekulu. 2007. The role of "Garsa" (Dobera glabra) for household food security at times of food shortage in Abàala Wereda, North Afar: ecological adaptation and socio-economic value, a study from Ethiopia. Oslo, Norway: Dryland Coordination Group, Report No. 49. 54 p.

VetaAs, O. R. 1992. Micro-site effects of trees and shrubs in dry savannas. Journal of Vegetation Science 3:337-344.

Vitousek, P. M. 1984. Litter fall, nutrient cycling, and nutrient limitation in tropical forests. Ecology 65:285-298.

Weltzin, J. E., S. R. Archer, and R. K. Heitschmidt. 1998. Defoliation and woody plant (Prosopis glandulosa) seedling regeneration: potential vs realized herbivory tolerance. Plant Ecology 138:127-135.

Zida, D., M. Tigabu, L. Samadogo, and P. C. Oden. 2008. Initial seedling morphological characteristics and field performance of two Sudanian savanna species in relation to nursery production period and watering regimes. Forest Ecology and Management 255:2151-2162. 